Review Article

\title{
Current Perspectives regarding Stem Cell-Based Therapy for Alzheimer's Disease
}

\author{
Kyeong-Ah Kwak, ${ }^{1}$ Seung-Pyo Lee, ${ }^{1}$ Jin-Young Yang, ${ }^{2}$ and Young-Seok Park $\mathbb{D}^{1}$ \\ ${ }^{1}$ Department of Oral Anatomy, Dental Research Institute, School of Dentistry, Seoul National University, Seoul, Republic of Korea \\ ${ }^{2}$ Department of Dental Hygiene, Daejeon Institute of Science and Technology, Daejeon, Republic of Korea
}

Correspondence should be addressed to Young-Seok Park; ayoayo7@snu.ac.kr

Received 19 November 2017; Accepted 15 January 2018; Published 1 March 2018

Academic Editor: Shimon Slavin

Copyright (C) 2018 Kyeong-Ah Kwak et al. This is an open access article distributed under the Creative Commons Attribution License, which permits unrestricted use, distribution, and reproduction in any medium, provided the original work is properly cited.

\begin{abstract}
Alzheimer's disease (AD), a progressive neurodegenerative disorder featuring memory loss and cognitive impairment, is caused by synaptic failure and the excessive accumulation of misfolded proteins. Many unsuccessful attempts have been made to develop new small molecules or antibodies to intervene in the disease's pathogenesis. Stem cell-based therapies cast a new hope for AD treatment as a replacement or regeneration strategy. The results from recent preclinical studies regarding stem cell-based therapies are promising. Human clinical trials are now underway. However, a number of questions remain to be answered prior to safe and effective clinical translation. This review explores the pathophysiology of AD and summarizes the relevant stem cell research according to cell type. We also briefly summarize related clinical trials. Finally, future perspectives are discussed with regard to their clinical applications.
\end{abstract}

\section{Introduction}

According to reports from the Alzheimer's Association, there are approximately 50 million people with dementia worldwide, accounting for approximately 800 billion dollars. Alzheimer's disease (AD) is the most frequent form of dementia, which shows clinical manifestations of progressive loss of memory and impairment of cognitive functions. The disease was first reported by Alois Alzheimer in 1907 [1]. As life expectancy rises and the population ages, the social burden of $\mathrm{AD}$ is predicted to soar [2,3]. Alzheimer's disease is multifactorial; therefore, it is difficult to determine its exact pathophysiologic mechanism [4]. However, synaptic failure is the main feature that is caused by neuronal loss in the region of the brain cortex and hippocampus due to the excessive accumulation of neurofibrillary tangles and $\beta$ amyloid $(A \beta)$ plaques [5-8]. However, approximately onethird of patients with a documented diagnosis of $\mathrm{AD}$ have no radiographic signs of amyloid on PET scans [9]. Therefore, more sophisticated approaches, including imaging and pathology, are likely needed in the diagnosis of $\mathrm{AD}[10,11]$.
There are two main types of AD: familial and sporadic. Familial AD comprises $<5 \%$ of cases and is associated with a distinct autosomal genetic mutation associated with the amyloid precursor protein (APP), presenilin-1 (PSEN-1), and presenilin-2 (PSEN-2) [5, 12-18]. In contrast, sporadic $\mathrm{AD}$ accounts for the majority of cases. It typically has a late onset and is thought to result from interactions between a complex genetic profile (including apolipoprotein [ApoE4]) and environmental factors such as cardiovascular disease, depression, and lower levels of education $[19,20]$.

The cardinal pathologic features of $\mathrm{AD}$ include the accumulation of two types of misfolded proteins $[21,22]$. One such protein is tau, which is a microtubule-associated protein that is important for axonal transport and structural support. When the tau protein becomes hyperphosphorylated, the microtubules lose their support and neurofibrillary tangles aggregate [23]. Although this process is closely associated with cognitive decline, tau mutations lead to frontotemporal dementia rather than $\mathrm{AD}[4]$. The other important protein in $\mathrm{AD}$ is $\mathrm{A} \beta$ protein, which is the abnormal sequential cleavage product of APP. The A $\beta$ aggregates to form senile plaques, 
which are known to cause calcium influx and neuronal cell death [24]. A $\beta$ oligomers are considered to be especially detrimental to synaptic and neuronal functions and result in cognitive dysfunction $[25,26]$. Mutations regarding APP and its processing are prominent characteristics of earlyonset familial $\mathrm{AD}$. Therefore, most patients with $\mathrm{AD}$ do not actually have these mutations. Instead, $60-75 \%$ of sporadic $\mathrm{AD}$ populations are ApoE4 carriers [27]. Several evidences support that ApoE4 has important roles in pathogenesis not only $\mathrm{A} \beta$ dependently but also independently $[4,28,29]$. Therefore, ApoE4 is thought to be an important gene in the semidominant inheritance of sporadic late-onset $\mathrm{AD}[14,15]$.

In addition to these two specific proteins, microglial activation and subsequent inflammatory responses are thought to contribute to the neurodegenerative symptoms of $\mathrm{AD}$ $[30,31]$. Activated microglia produce several proinflammatory cytokines, including interleukin- (IL-) $1 \beta$ and tumor necrosis factor- (TNF-) $\alpha$, as well as nitric oxide (NO) [32-35]. Oxidative stress and mitochondrial dysfunction have also been suggested to play a role in $\mathrm{AD}$ pathogenesis [36-41]. The dysfunction of the GABAergic neuronal system is thought to contribute to learning and memory deficits in patients with $\mathrm{AD}[4,17,42-52]$.

Until now, the main therapeutic strategy in $\mathrm{AD}$ of most drug developments has focused on facilitating amyloid clearance or preventing amyloid production [4, 53-55]. Before the amyloid pathway was proposed [56], clinical trials using cholinesterase inhibitors were performed based on the notion that memory is closely related to cholinergic systems [57-59]. Therefore, a number of small molecules and antibodies targeting the amyloid cascade have been developed and investigated in clinical trials [53, 54, 60-67]. Unfortunately, the results from almost all of these trials were far from satisfactory. There is little evidence to support the efficacy of such treatments [68]. Dementia prevention trials have also used many other agents, including antihypertensive drugs, NSAIDs, vitamin E, selenium, and Ginkgo biloba [69-73], all of which had no effect on reducing the risk of AD.

The conventional mediations investigated have yielded no clinical benefits for $\mathrm{AD}$. Therefore, there is a large unmet need for patients suffering from AD. Recently, stem cells have gained interest as a potential alternative to conventional medicines or surgery. Several attempts have been made to appreciate the clinical applications of stem cells with regard to an advanced understanding of the cellular and molecular mechanisms of neuroregeneration and neurodegeneration [74-78]. Stem cell-based therapy is a potentially promising strategy in the treatment of various neurologic disorders that do not otherwise have any effective treatments, including stroke, Parkinson's disease, Huntington's disease, amyotrophic lateral sclerosis, and $\mathrm{AD}$ [79-83]. This article reviews the current literature according to stem cell type and discusses the future of stem cell-based therapy in Alzheimer's disease.

\section{Expected Mode of Action}

Stem cells can incorporate into existing neural networks [84]. They also secrete a variety of neurotrophic factors to modulate neuroplasticity and neurogenesis [77, 78], which appear to increase brain acetylcholine levels, ultimately leading to improved memory and cognitive function in an animal model [75]. The primary modes of actions of stem cell-based therapy can be categorized into endogenous and exogenous ways depending on the mechanisms of action [19]. Traditionally, cell-based therapies have sought to replace damaged tissue through tissue repopulation either by transdifferentiation or by direct participation of infused stem cells [84]. However, the current understanding suggests that engrafted stem cells are not a main source for newly generated neurons [76, 85-90]. Furthermore, unlike in Parkinson's disease, AD is characterized by the death of various distinct nerve cell types. This variability precludes the feasibility of transplantation of specific mature cell types.

Rather than using the cell replacement paradigm, therefore, there is a growing interest in the stimulation of endogenous repair using paracrine effects. The trophic support provided by transplanted stem cells improves the microenvironment and promotes the survival of affected/ remaining nerve cells $[3,91]$. Using this strategy, the primary target to stimulate hippocampal neoneurogenesis (in order to compensate for neurodegeneration) is the upregulation of resident neural stem cell niches. Hippocampal neoneurogenesis is believed to play a key role in memory and learning. Neurotrophic factor (BDNF), nerve growth factor (NGF), insulin growth factor-1 (IGF-1), and vascular endothelial growth factor (VEGF) are suggested paracrine mediators from transplanted stem cells [92]. Unfortunately, the potential for neurogenesis in humans decreases substantially with older age, which is primarily when AD occurs $[93,94]$. In addition, the modulation of inflammation has been proposed as another mechanism of action [76].

\section{Stem Cell Types}

3.1. Embryonic Stem Cells. Human embryonic stem cells (ESCs) were first characterized in 1998 from the inner mass of the blastocyst [95]. If their pluripotency could be accurately controlled into the desired neural phenotypes, no other alternative cells would replace them as a better cell source for cell replacement strategies. In vitro attempts to differentiate ESCs into several specific neural cell types have been successful, including dopaminergic neurons [96-102]. Indeed, an ex vivo slice culture study reported stable generations and the functional integration of cholinergic neuron from human ESCs [103]. Despite the ongoing preclinical studies, there are a number of issues that remain with the current technologies, including tumor formation, phenotype instability, and low survival rate of transplanted cells [104, 105]. Furthermore, there are ethical and immunogenic limitations that may preclude the clinical usage of ESCs. In fact, given the ethical policies and regulation, there are few clinical trials that have involved ESCs [106, 107].

3.2. Induced Pluripotent Stem Cells. Induced pluripotent stem cells (iPSCs) were first developed from mouse fibroblasts in 2006. These cells are reprogrammed into a state of pluripotency that is similar to that of ESCs [108]. iPSCs are thought 
to be able to differentiate into a variety of cells, including neurons [109] and neurospheres [110]. Several encouraging reports have been published showing that some neuronal subtypes can be generated and automated using iPSCs [84, 111-114]. For example, iPSC-derived glia could be used for research regarding inflammatory response in $\mathrm{AD}$ [115]. Another study used iPSCs to derive macrophages that could express neprilysin, the $\mathrm{A} \beta$-degrading protease [116].

Despite this promising evidence, however, the following unresolved issues regarding iPSC usage constitute big hurdles to its clinical application: teratoma formation, longterm safety and efficacy, tumorigenicity, immunogenicity, patient-derived genetic defects, and optimal reprogramming [117-121]. Ethical guidelines and standards have been developed regarding the use of iPSCs [122, 123]. Therefore, applications of iPSCs in AD, until now, have been more focused on the development of cell-based disease models than on treatments [124-130]. Basal forebrain cholinergic neurons have been of special interest, as they demonstrate dysfunction in early $\mathrm{AD}$ [131]. In later stages of $\mathrm{AD}$, strategies using iPSCs should be more elaborated due to widespread degeneration $[6,132]$. Unfortunately, prior studies have found that human iPSC lines have only a $10-50 \%$ differentiation potential for neurons, as compared to ESCs, which have a nearly $90 \%$ differentiation potential $[133,134]$.

3.3. Neural Stem Cells. In the adult brain, multipotent neural stem cells (NSCs) reside in the subgranular zone (SGZ) and subventricular zone (SVZ) [81]. They can differentiate into a variety of cell types, including neurons, astrocytes, and oligodendrocytes. NSCs can also be derived from fetal and postmortem neonatal brain tissues [76] or differentiated from ESCs and iPSCs [135-137]. In animal AD models, transplanted NSCs differentiated into mature brain cell types [138-141]. For successful neuronal replacement, the grafted cells should be distributed throughout the affected tissue (maintaining its original identity) and then integrated into the host brain's functional environment [142]. However, it is unknown if NSCs can generate into specific neural cell types. Interestingly, the migration and differentiation of grafted NSCs appeared substantially influenced by the recipient environment [143, 144]. However, there is frequent unwanted differentiation into nonneuronal glial cell types reported with NSCs [140].

It is not clear how much neuronal replacement contributes to the beneficial effects of NSC transplantation $[140,145,146]$. As is the case in the transplantation of other stem cells, the paracrine effect after NSC transplantation has gained more support than has cell replacement [75, 147]. In particular, brain-derived neurotrophic factor (BDNF) secreted from NSCs is essential for rescuing cognitive function in $\mathrm{AD}[148,149]$. In addition, NSC transplantation has been reported to have neuroprotective, neuroregenerative, and/or immune modulatory roles [148, 150-153]. Tumorigenesis and functional recovery warrant further investigations using NSC transplantation [145].

The NSCs can be induced from other cells. The generation of induced NSCs (iNSCs) from fibroblasts, astrocytes, and Sertoli cells has been reported [154-161].
NSCs that are derived from ESCs have also been investigated and differentiated into astrocyte-like cells [162]. However, the in vivo viability of iNSCs after transplantation is still considered unpredictable [154, 156-158, 163]. As a modified strategy, therefore, NSCs can be used as delivery vehicles to carry therapeutic agents such as neprily$\sin [164,165]$. Using NSC-based therapy for drug delivery, rather than for neuronal replacement, has gained interest recently $[74,76,135,149,166]$.

3.4. Mesenchymal Stem Cells. Mesenchymal stem cells (MSCs) have received special interest in the treatment of $\mathrm{AD}$ given their excellent accessibility, relative ease of handling, extensively studied characteristics, and broad range of differentiating potential (including neuronal cells) $[78,167]$. MSCs are additionally advantageous as cell-based therapies given that they can be administered intravenously, exhibit blood-brain barrier penetration, have low tumorigenicity, and elicit less of an immune response (than do other cell-based therapies) [168, 169].

Unfortunately, there is little evidence for the functionality of MSC-derived neurons in vivo with low rates of neuronal differentiation [170]. Rather than for neuronal replacement, the beneficial effects of MSCs seemed to be mediated by their secreted factors, which stimulate the proliferation, differentiation, and survival of the neurogenic niche [168, 171-178]. Well-known anti-inflammatory and immune modulatory characteristics are also presumed to contribute to recovery, which involves a number of cytokines [171, 175, 177, 178]. Notably, the homogeneity of MSCs is suspected in their phenotypic expression and differentiation [179].

There is a wide variety of sources from which MSCs are acquired. Bone marrow-derived MSCs (BM-MSCs) have been most widely investigated since a long time ago [162]. BM-MSCs gain their immunomodulatory ability through the release of soluble factors, including IL-6, IL-10, TGF- $\beta$, and PGE2 [180-182]. They are known to inhibit the functioning of monocyte-derived dendritic cells and to alter the natural killer cell phenotype $[183,184]$. Adipose tissue is one of the most advantageous sources of MSCs. Adipose tissue-derived MSCs (AT-MSCs) can differentiate into neuron-like and astrocyte-like cells [185]. They seem to share a common transcriptional profile for stemness with BMMSCs [186, 187]. AT-MSCs also secrete many neurotrophic factors [188-193]. Finally, umbilical cord blood-derived MSCs (UCB-MSCs) can differentiate into neuron-like cells. These cells have been studied in an AD mouse model, as well as clinically [194]. One suggested mechanism of action is the activation of M2-like microglia [177, 195].

3.5. Other Cells. Several other stem cells have been investigated with regard to their potential in neuronal regeneration, including neural crest stem cells [196-200], hematopoietic stem cells [201], human dental pulp stem cells [202-204], and olfactory ensheathing cells [205-210]. Remarkably, the somatic cell nuclear transfer procedure involving olfactory ensheathing cells is another promising technology via the intranasal route [211-214]. 


\section{Clinical Trials}

There was sufficient animal model evidence for MSC-based therapies to approve the initiation of clinical trials in patients with AD since 2011 (Table 1). Intravenous infusion is the most preferred delivery method of stem cells, and UCBMSCs were the most frequently used cell source. According to Kim et al., human UCB-MSCs were transplanted into the hippocampus and precuneus stereotactically. Although there were no severe adverse events, the group did not identify any significant clinical efficacy in cognitive decline (ClinicalTrials.gov, NCT01297218, NCT01696591) [175]. Furthermore, there were no changes in pathology or observed neuroprotective effects $[175,177,178]$. These results may be partly due to neuroimaging, which can be an insensitive modality for detecting such changes compared to that of postmortem biochemical analyses.

Three additional clinical trials using UCB-MSCs are currently underway. One involves intravenous injection in an open-label phase I/II study (NCT01547689), while another involves intravenous infusion in a double-blind randomized placebo-controlled study (NCT02672306). The third study involves intraventricular injection of the Ommaya reservoir system (NCT02054208). As an alternative source of MSCs, one trial will assess the outcome of ATMSCs (NCT02912169). A phase 2A study (NCT02600130, NCT02833792) will utilize the intravenous administration of allogenic ischemia-tolerant allogeneic BM-MSCs grown in hypoxic conditions [215].

\section{Discussion}

Cognitive declines in $\mathrm{AD}$ result from the loss of neurons and neuronal processes, which result from diverse factors. The pathways of toxic protein synthesis and degradation in $\mathrm{AD}$ have been rigorously investigated to determine the most effective disease management [132]. To date, efforts to develop target-specific drugs have not succeeded. The progressive and devastating nature of $\mathrm{AD}$ requires breakthrough therapy to satisfy the unmet needs of patients. Cell-based therapies may offer a promising solution to this need. They may be able to not only reverse the progression of $\mathrm{AD}$ but also improve cell function.

Technologic advances have sought to generate various types of neuronal cells with glial cells. These investigations have led to the replacement and regeneration concept of stem cell-based therapies in AD. Substantial achievements have been made in animal models as a proof of concept $[29,143,145,149,162,165,166,216-219]$. Despite the promising results of preclinical studies, human clinical trials are still in their infancy with regard to stem cell therapies. There are many more questions that must be answered prior to transferring this technology from the bench to the clinic.

There are several cardinal questions that ought to be addressed for the clinical translation of stem cell therapies, such as optimum cell source, long-term safety, and routes of delivery. The brain is an immune-privileged organ; therefore, it is important to consider immune rejection when using stem cell therapies [142]. Given that most AD patients are elderly, special caution is necessary regarding the difference in donor cell proliferation capability [216, 220, 221]. The variability of donor cells and unstandardized reprogramming methods could also pose a problem $[222,223]$. The current, general concerns regarding stem cell-based therapy are as follows: tumorigenicity, immune reaction, contamination while handling, risks from genetic modification, risks of administration modality, unintended migration, unwanted transdifferentiation, infection, and death of the transplant [224227]. There are also ethical concerns with regard to certain cell sources.

Alzheimer's disease involves the death of variable neuronal cell types. In its early phases, the hippocampal circuitry can be a major therapeutic target [19]. In advanced phases, additional neuronal subtypes become involved. Therefore, the therapeutic strategy will become more complicated as the disease progresses. In clinical trials, extremely elaborate controls must be used, unless each involved cell type is transplanted (at the same time or sequentially). In this regard, pluripotent stem cells might be advantageous in $\mathrm{AD}$ over another source. However, the current evidence does not suggest that cell replacement is the mechanism of stem cell-based therapy.

The iPSC approach deserves attention given its biological relevance. The major advantages of this approach are that iPSCs can be made autologous, be differentiated into intended cell types, and provide a sufficient quantity [132]. In order to advance toward successful iPSC-based therapies for $\mathrm{AD}$, the following parameters must be met: establish haplobanks of HLA-typed iPSCs for off-the-shelf cell therapies [228], establish protocols to create neuronal stem cells or hippocampal neurons with appropriate surgical and tracking techniques, and establish an astrocyte-generation technique for providing trophic agents [226]. We believe that the development of individual cell tracking and real-time imaging will be essential [229-233].

Eventually, there is a need for precise manufacturing practices in the preparation and handling of transplantable cells for clinical use. Prior to their clinical use, if able to be manipulated in vitro, all grafted cells would ideally be transgenically equipped with a molecular "kill switch" that could be easily activated in the event of adverse effects. $\mathrm{AD}$ can be a relatively slowly progressive disease; therefore, clinical trials are expected to require many years to demonstrate success in halting or reversing disease progression. The safe and ethical future of stem cell therapies, especially for $\mathrm{AD}$, will likely be slow, expensive, and tightly controlled [166]. However, given the unique nature of stem cell-based therapies, regulatory agents are needed to develop new regulatory policies to foster their appropriate development and success.

\section{Conclusion}

Alzheimer's disease is a progressive neurodegenerative disease for which there is no effective treatment currently. Stem cell-based therapies may become an effective therapeutic alternative (to conventional therapies) due to their 


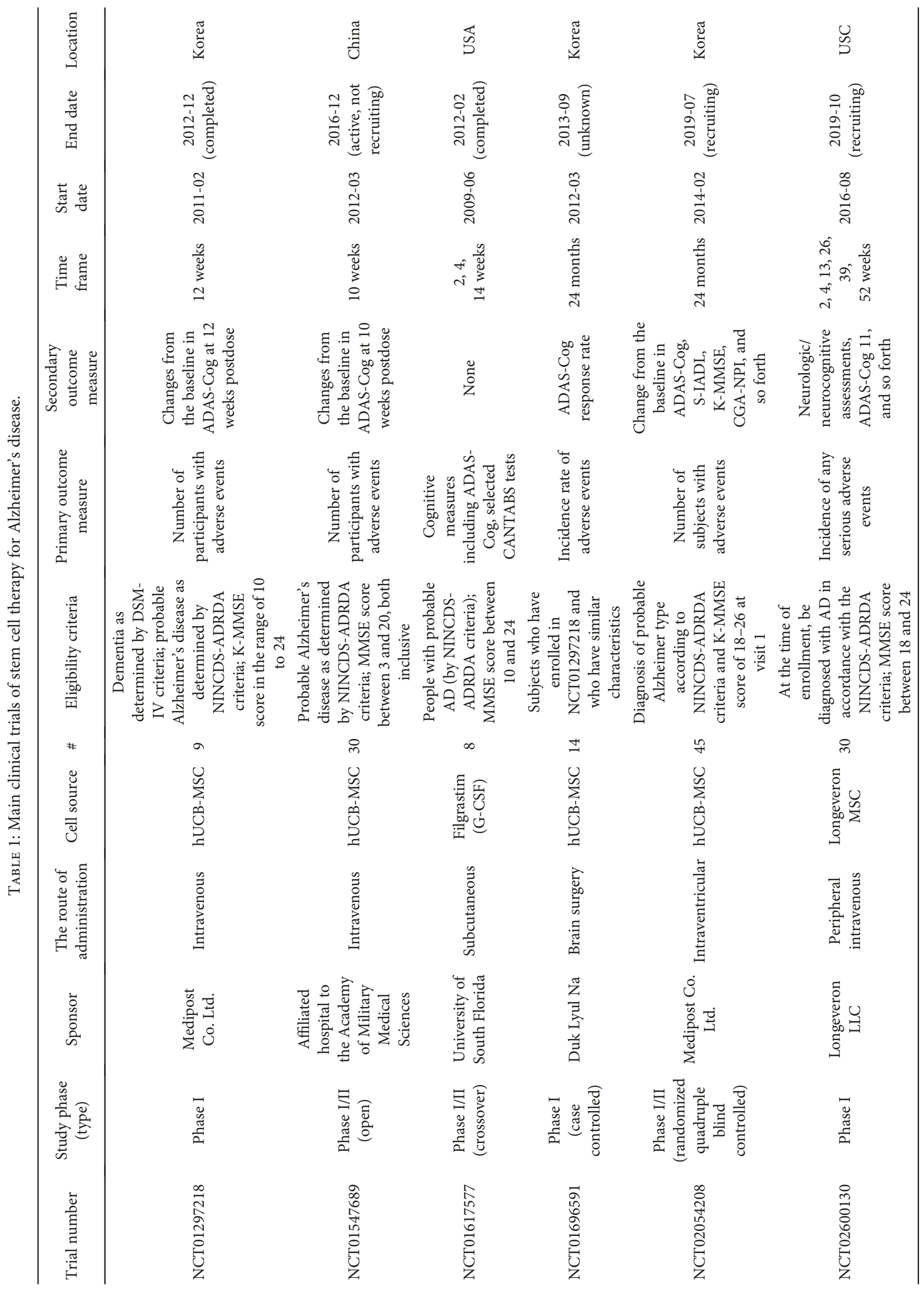




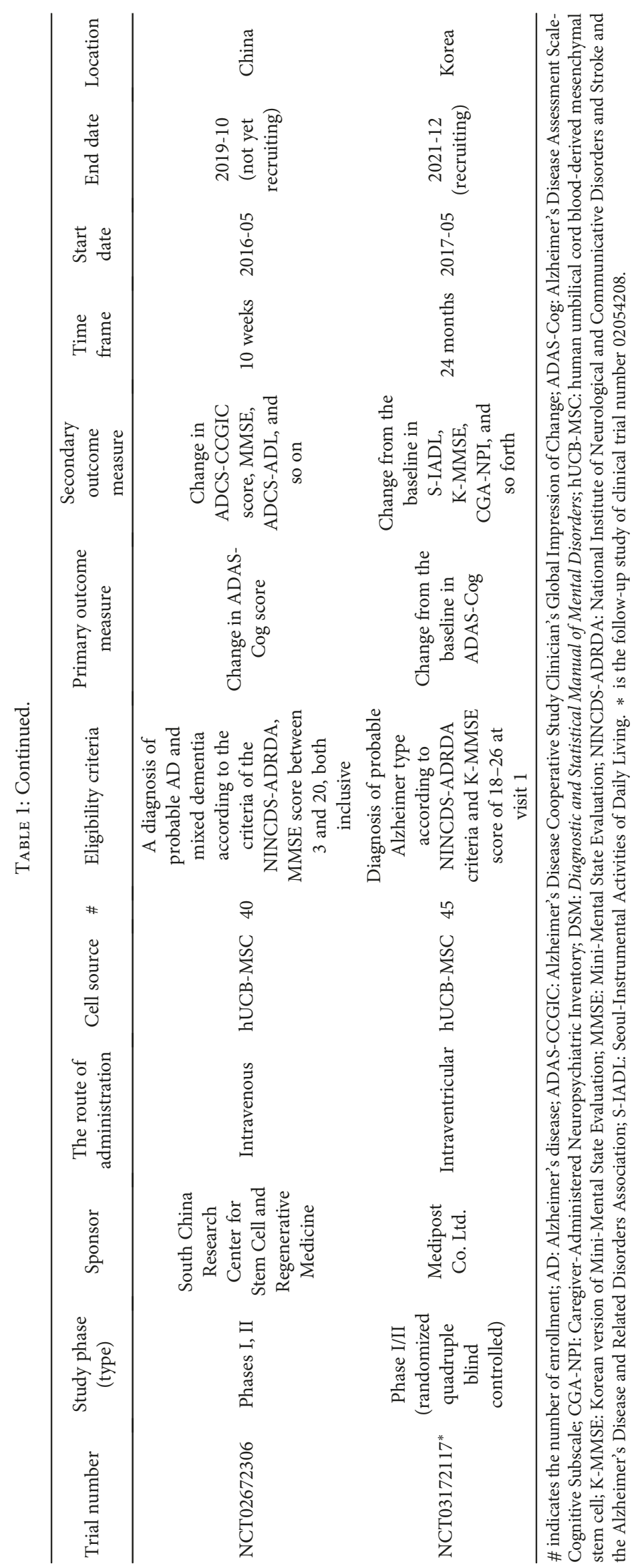


regenerative potential. Although the mechanism of action of stem cell therapies remains incompletely elucidated, a number of preclinical studies have provided promising results. However, human clinical trials are still in their infancy. For the successful clinical translation of this technology, further relevant animal studies and clinical trials (with standardized protocols) are needed. There are many questions left unanswered regarding the safety, efficacy, ethical issues, and regulatory framework of stem cell-based therapies. There is a growing hope for patient-specific individualized stem cellbased therapy. This review attempts to provide a synopsis of stem cell-based therapy for AD in particular. We describe the pathophysiology of $\mathrm{AD}$ and proposed mechanisms of stem cell therapies. Preclinical results according to the cell type and clinical trials are briefly summarized. Future perspectives are also discussed.

\section{Conflicts of Interest}

All authors have no conflicts of interest relevant to this article.

\section{Authors' Contributions}

Kyeong-Ah Kwak and Seung-Pyo Lee contributed equally to this work.

\section{Acknowledgments}

This research was supported by a grant (17172MFDS202) from the Ministry of Food and Drug Safety of Korea.

\section{References}

[1] J. Hong, H. Jin, J. Han et al., "Infusion of human umbilical cord-derived mesenchymal stem cells effectively relieves liver cirrhosis in DEN-induced rats," Molecular Medicine Reports, vol. 9, no. 4, pp. 1103-1111, 2014.

[2] A. Burns, E. J. Byrne, and K. Maurer, "Alzheimer's disease," Lancet, vol. 360, no. 9327, pp. 163-165, 2002.

[3] J. S. Lunn, S. A. Sakowski, J. Hur, and E. L. Feldman, "Stem cell technology for neurodegenerative diseases," Annals of Neurology, vol. 70, no. 3, pp. 353-361, 2011.

[4] Y. Huang and L. Mucke, "Alzheimer mechanisms and therapeutic strategies,” Cell, vol. 148, no. 6, pp. 1204-1222, 2012.

[5] D. J. Selkoe, "Alzheimer's disease: genes, proteins, and therapy," Physiological Reviews, vol. 81, no. 2, pp. 741-766, 2001.

[6] D. J. Selkoe, "Alzheimer's disease is a synaptic failure," Science, vol. 298, no. 5594, pp. 789-791, 2002.

[7] R. L. Nussbaum and C. E. Ellis, "Alzheimer's disease and Parkinson's disease," The New England Journal of Medicine, vol. 348, no. 14, pp. 1356-1364, 2003.

[8] C. Reitz, C. Brayne, and R. Mayeux, "Epidemiology of Alzheimer disease," Nature Reviews Neurology, vol. 7, no. 3, pp. 137-152, 2011.

[9] P. M. Doraiswamy, R. A. Sperling, K. Johnson et al., "Florbetapir F 18 amyloid PET and 36-month cognitive decline: a prospective multicenter study," Molecular Psychiatry, vol. 19, no. 9, pp. 1044-1051, 2014.
[10] O. G. James, P. M. Doraiswamy, and S. Borges-Neto, "PET imaging of tau pathology in Alzheimer's disease and tauopathies," Frontiers in Neurology, vol. 6, p. 38, 2015.

[11] R. A. Sperling, P. S. Aisen, L. A. Beckett et al., "Toward defining the preclinical stages of Alzheimer's disease: recommendations from the National Institute on AgingAlzheimer's Association workgroups on diagnostic guidelines for Alzheimer's disease," Alzheimers Dement, vol. 7, no. 3, pp. 280-292, 2011.

[12] V. P. Prasher, M. J. Farrer, A. M. Kessling et al., "Molecular mapping of Alzheimer-type dementia in Down's syndrome," Annals of Neurology, vol. 43, no. 3, pp. 380383, 1998.

[13] K. H. Ashe and K. R. Zahs, "Probing the biology of Alzheimer's disease in mice," Neuron, vol. 66, no. 5, pp. 631-645, 2010.

[14] L. Bertram, C. M. Lill, and R. E. Tanzi, "The genetics of Alzheimer disease: back to the future," Neuron, vol. 68, no. 2, pp. 270-281, 2010.

[15] E. Genin, D. Hannequin, D. Wallon et al., "APOE and Alzheimer disease: a major gene with semi-dominant inheritance," Molecular Psychiatry, vol. 16, no. 9, pp. 903907, 2011.

[16] C. Marchetti and H. Marie, "Hippocampal synaptic plasticity in Alzheimer's disease: what have we learned so far from transgenic models?," Reviews in the Neurosciences, vol. 22, no. 4, pp. 373-402, 2011.

[17] J. J. Palop and L. Mucke, "Amyloid- $\beta$-induced neuronal dysfunction in Alzheimer's disease: from synapses toward neural networks," Nature Neuroscience, vol. 13, no. 7, pp. 812-818, 2010.

[18] H. W. Querfurth and F. M. LaFerla, "Alzheimer's disease," The New England Journal of Medicine, vol. 362, no. 4, pp. 329-344, 2010.

[19] T. Duncan and M. Valenzuela, "Alzheimer's disease, dementia, and stem cell therapy," Stem Cell Research \& Therapy, vol. 8, no. 1, p. 111, 2017.

[20] T. Persson, B. O. Popescu, and A. Cedazo-Minguez, "Oxidative stress in Alzheimer's disease: why did antioxidant therapy fail?," Oxidative Medicine and Cellular Longevity, vol. 2014, Article ID 427318, 11 pages, 2014.

[21] S. J. Allen, J. J. Watson, and D. Dawbarn, "The neurotrophins and their role in Alzheimer's disease," Current Neuropharmacology, vol. 9, no. 4, pp. 559-573, 2011.

[22] C. B. Eckman and E. A. Eckman, "An update on the amyloid hypothesis,” Neurologic Clinics, vol. 25, no. 3, pp. 669-682, 2007.

[23] B. Kuhla, C. Haase, K. Flach, H. J. Luth, T. Arendt, and G. Munch, "Effect of pseudophosphorylation and crosslinking by lipid peroxidation and advanced glycation end product precursors on tau aggregation and filament formation," Journal of Biological Chemistry, vol. 282, no. 10, pp. 6984-6991, 2007.

[24] A. Demuro, M. Smith, and I. Parker, "Single-channel Ca ${ }^{2+}$ imaging implicates $\mathrm{A} \beta 1-42$ amyloid pores in Alzheimer's disease pathology," Journal of Cell Biology, vol. 195, no. 3, pp. 515-524, 2011.

[25] A. N. Patel and J. H. Jhamandas, "Neuronal receptors as targets for the action of amyloid-beta protein $(\mathrm{A} \beta)$ in the brain," Expert Reviews in Molecular Medicine, vol. 14, article e2, 2012. 
[26] G. L. Wenk, "Neuropathologic changes in Alzheimer's disease," Journal of Clinical Psychiatry, vol. 64, Supplement 9, pp. 7-10, 2003.

[27] L. A. Farrer, L. A. Cupples, J. L. Haines et al., "Effects of age, sex, and ethnicity on the association between apolipoprotein E genotype and Alzheimer disease: a meta-analysis. APOE and Alzheimer Disease Meta Analysis Consortium," JAMA, vol. 278, no. 16, pp. 1349-1356, 1997.

[28] Y. Huang, "Apolipoprotein E and Alzheimer disease," Neurology, vol. 66, Supplement 1, pp. S79-S85, 2006.

[29] S. U. Kim and J. de Vellis, "Stem cell-based cell therapy in neurological diseases: a review," Journal of Neuroscience Researsch, vol. 87, no. 10, pp. 2183-2200, 2009.

[30] P. Eikelenboom, C. Bate, W. A. Van Gool et al., "Neuroinflammation in Alzheimer's disease and prion disease," Glia, vol. 40, no. 2, pp. 232-239, 2002.

[31] C. Millington, S. Sonego, N. Karunaweera et al., "Chronic neuroinflammation in Alzheimer's disease: new perspectives on animal models and promising candidate drugs," BioMed Research International, vol. 2014, Article ID 309129, 10 pages, 2014.

[32] B. T. Baune, G. Ponath, M. Rothermundt, A. Roesler, and K. Berger, "Association between cytokines and cerebral MRI changes in the aging brain," Journal of Geriatric Psychiatry and Neurology, vol. 22, no. 1, pp. 23-34, 2009.

[33] X. Delbeuck, M. Van der Linden, and F. Collette, "Alzheimer's disease as a disconnection syndrome?," Neuropsychology Review, vol. 13, no. 2, pp. 79-92, 2003.

[34] G. Münch, R. Schinzel, C. Loske et al., “Alzheimer's disease synergistic effects of glucose deficit, oxidative stress and advanced glycation endproducts," Journal of Neural Transmission, vol. 105, no. 4, pp. 439-461, 1998.

[35] D. G. Walker and L. F. Lue, "Investigations with cultured human microglia on pathogenic mechanisms of Alzheimer's disease and other neurodegenerative diseases," Journal of Neuroscience Research, vol. 81, no. 3, pp. 412425, 2005.

[36] V. Bernard, M. Decossas, I. Liste, and B. Bloch, "Intraneuronal trafficking of G-protein-coupled receptors in vivo," Trends in Neurosciences, vol. 29, no. 3, pp. 140147, 2006.

[37] M. Y. Cha, S. H. Han, S. M. Son et al., "Mitochondria-specific accumulation of amyloid $\beta$ induces mitochondrial dysfunction leading to apoptotic cell death," PLoS One, vol. 7, no. 4, article e34929, 2012.

[38] A. Federico, E. Cardaioli, P. Da Pozzo, P. Formichi, G. N. Gallus, and E. Radi, "Mitochondria, oxidative stress and neurodegeneration," Journal of the Neurological Sciences, vol. 322, no. 1-2, pp. 254-262, 2012.

[39] D. P. Jones, "Radical-free biology of oxidative stress," American Journal of Physiology-Cell Physiology, vol. 295, no. 4, pp. C849-C868, 2008.

[40] M. A. Meraz-Ríos, D. Toral-Rios, D. Franco-Bocanegra, J. Villeda-Hernández, and V. Campos-Peña, "Inflammatory process in Alzheimer's disease," Frontiers in Integrative Neuroscience, vol. 7, p. 59, 2013.

[41] D. G. Wilkinson, P. T. Francis, E. Schwam, and J. PayneParrish, "Cholinesterase inhibitors used in the treatment of Alzheimer's disease: the relationship between pharmacological effects and clinical efficacy," Drugs \& Aging, vol. 21, no. 7, pp. 453-478, 2004.
[42] I. Brosh and E. Barkai, "Learning-induced enhancement of feedback inhibitory synaptic transmission," Learning \& Memory, vol. 16, no. 7, pp. 413-416, 2009.

[43] K. A. Celone, V. D. Calhoun, B. C. Dickerson et al., "Alterations in memory networks in mild cognitive impairment and Alzheimer's disease: an independent component analysis," The Journal of Neuroscience, vol. 26, no. 40, pp. 10222-10231, 2006.

[44] Y. Cui, R. M. Costa, G. G. Murphy et al., "Neurofibromin regulation of ERK signaling modulates GABA release and learning," Cell, vol. 135, no. 3, pp. 549-560, 2008.

[45] B. C. Dickerson, D. H. Salat, J. F. Bates et al., "Medial temporal lobe function and structure in mild cognitive impairment," Annals of Neurology, vol. 56, no. 1, pp. 2735, 2004.

[46] B. C. Dickerson, D. H. Salat, D. N. Greve et al., "Increased hippocampal activation in mild cognitive impairment compared to normal aging and AD," Neurology, vol. 65, no. 3, pp. 404-411, 2005.

[47] A. Hämäläinen, M. Pihlajamäki, H. Tanila et al., "Increased fMRI responses during encoding in mild cognitive impairment," Neurobiology of Aging, vol. 28, no. 12, pp. 18891903, 2007.

[48] M. Jasinska, E. Siucinska, A. Cybulska-Klosowicz et al., "Rapid, learning-induced inhibitory synaptogenesis in murine barrel field," The Journal of Neuroscience, vol. 30, no. 3, pp. 1176-1184, 2010.

[49] W. J. Meilandt, G. Q. Yu, J. Chin et al., "Enkephalin elevations contribute to neuronal and behavioral impairments in a transgenic mouse model of Alzheimer's disease," The Journal of Neuroscience, vol. 28, no. 19, pp. 5007-5017, 2008.

[50] D. Nitz and B. McNaughton, "Differential modulation of CA1 and dentate gyrus interneurons during exploration of novel environments," Journal of Neurophysiology, vol. 91, no. 2, pp. 863-872, 2004.

[51] R. O. Sanchez-Mejia, J. W. Newman, S. Toh et al., "Phospholipase $\mathrm{A}_{2}$ reduction ameliorates cognitive deficits in a mouse model of Alzheimer's disease," Nature Neuroscience, vol. 11, no. 11, pp. 1311-1318, 2008.

[52] L. Verret, E. O. Mann, G. B. Hang et al., "Inhibitory interneuron deficit links altered network activity and cognitive dysfunction in Alzheimer model," Cell, vol. 149, no. 3, pp. 708-721, 2012.

[53] S. Salloway, R. Sperling, N. C. Fox et al., "Two phase 3 trials of bapineuzumab in mild-to-moderate Alzheimer's disease," The New England Journal of Medicine, vol. 370, no. 4, pp. 322-333, 2014.

[54] R. S. Doody, R. Raman, M. Farlow et al., "A phase 3 trial of semagacestat for treatment of Alzheimer's disease," The New England Journal of Medicine, vol. 369, no. 4, pp. 341350, 2013.

[55] T. E. Golde, L. S. Schneider, and E. H. Koo, "Anti-a $\beta$ therapeutics in Alzheimer's disease: the need for a paradigm shift," Neuron, vol. 69, no. 2, pp. 203-213, 2011.

[56] J. Hardy and D. Allsop, "Amyloid deposition as the central event in the aetiology of Alzheimer's disease," Trends in Pharmacological Sciences, vol. 12, no. 10, pp. 383388, 1991.

[57] J. Birks, J. Grimley Evans, V. Iakovidou, and M. Tsolaki, "Rivastigmine for Alzheimer's disease," Cochrane Database of Systematic Reviews, no. 4, article CD001191, 2000. 
[58] J. Birks and R. J. Harvey, "Donepezil for dementia due to Alzheimer's disease," Cochrane Database of Systematic Reviews, no. 1, article CD001190, 2006.

[59] C. Loy and L. Schneider, "Galantamine for Alzheimer's disease and mild cognitive impairment," Cochrane Database of Systematic Reviews, no. 1, article CD001747, 2006.

[60] P. Aisen, S. Gauthier, B. Vellas et al., "Alzhemed: a potential treatment for Alzheimer's disease," Current Alzheimer Research, vol. 4, no. 4, pp. 473-478, 2007.

[61] R. C. Green, L. S. Schneider, D. A. Amato et al., "Effect of tarenflurbil on cognitive decline and activities of daily living in patients with mild Alzheimer disease: a randomized controlled trial," JAMA, vol. 302, no. 23, pp. 2557-2564, 2009.

[62] S. Salloway, R. Sperling, and H. R. Brashear, "Phase 3 trials of solanezumab and bapineuzumab for Alzheimer's disease," The New England Journal of Medicine, vol. 370, no. 15, p. 1460, 2014.

[63] V. Coric, C. H. van Dyck, S. Salloway et al., "Safety and tolerability of the $\gamma$-secretase inhibitor avagacestat in a phase 2 study of mild to moderate Alzheimer disease," Archives of Neurology, vol. 69, no. 11, pp. 1430-1440, 2012.

[64] R. Dodel, A. Rominger, P. Bartenstein et al., "Intravenous immunoglobulin for treatment of mild-to-moderate Alzheimer's disease: a phase 2, randomised, double-blind, placebo-controlled, dose-finding trial," The Lancet Neurology, vol. 12, no. 3, pp. 233-243, 2013.

[65] R. S. Doody, R. G. Thomas, M. Farlow et al., "Phase 3 trials of solanezumab for mild-to-moderate Alzheimer's disease," The New England Journal of Medicine, vol. 370, no. 4, pp. 311-321, 2014.

[66] S. Salloway, R. Sperling, R. Keren et al., "A phase 2 randomized trial of ELND005, scyllo-inositol, in mild to moderate Alzheimer disease," Neurology, vol. 77, no. 13, pp. 12531262, 2011.

[67] E. R. Siemers, K. L. Sundell, C. Carlson et al., "Phase 3 solanezumab trials: secondary outcomes in mild Alzheimer's disease patients," Alzheimer's \& Dementia, vol. 12, no. 2, pp. 110-120, 2016.

[68] S. Kile, W. Au, C. Parise et al., "IVIG treatment of mild cognitive impairment due to Alzheimer's disease: a randomised double-blinded exploratory study of the effect on brain atrophy, cognition and conversion to dementia," Journal of Neurology, Neurosurgery \& Psychiatry, vol. 88, no. 2, pp. 106-112, 2017.

[69] R. J. Kryscio, E. L. Abner, F. A. Schmitt et al., “A randomized controlled Alzheimer's disease prevention trial's evolution into an exposure trial: the PREADViSE trial," The Journal of Nutrition, Health \& Aging, vol. 17, no. 1, pp. 72-75, 2013.

[70] R. Peters, N. Beckett, F. Forette et al., "Incident dementia and blood pressure lowering in the hypertension in the Very Elderly Trial cognitive function assessment (HYVET-COG): a double-blind, placebo controlled trial," The Lancet Neurology, vol. 7, no. 8, pp. 683-689, 2008.

[71] ADAPT Research Group, C. G. Lyketsos, J. C. Breitner et al., "Naproxen and celecoxib do not prevent AD in early results from a randomized controlled trial," Neurology, vol. 68, no. 21, pp. 1800-1808, 2007.

[72] S. T. DeKosky, J. D. Williamson, A. L. Fitzpatrick et al., "Ginkgo biloba for prevention of dementia: a randomized controlled trial," JAMA, vol. 300, no. 19, pp. 2253-2262, 2008.
[73] B. Vellas, N. Coley, P. J. Ousset et al., "Long-term use of standardised ginkgo biloba extract for the prevention of Alzheimer's disease (GuidAge): a randomised placebocontrolled trial," The Lancet Neurology, vol. 11, no. 10, pp. 851-859, 2012.

[74] A. K. L. Liu, "Stem cell therapy for Alzheimer's disease: hype or hope?," Bioscience Horizons, vol. 6, article hzt011, 2013.

[75] D. Park, Y. H. Yang, D. K. Bae et al., "Improvement of cognitive function and physical activity of aging mice by human neural stem cells over-expressing choline acetyltransferase," Neurobiology of Aging, vol. 34, no. 11, pp. 2639-2646, 2013.

[76] P. L. Martínez-Morales, A. Revilla, I. Ocaña et al., "Progress in stem cell therapy for major human neurological disorders," Stem Cell Reviews and Reports, vol. 9, no. 5, pp. 685-699, 2013.

[77] A. M. Enciu, M. I. Nicolescu, C. G. Manole, D. F. Mureşanu, L. M. Popescu, and B. O. Popescu, "Neuroregeneration in neurodegenerative disorders," BMC Neurology, vol. 11, no. 1, p. 75, 2011.

[78] D. Park, G. Yang, D. K. Bae et al., "Human adipose tissuederived mesenchymal stem cells improve cognitive function and physical activity in ageing mice," Journal of Neuroscience Research, vol. 91, no. 5, pp. 660-670, 2013.

[79] A. Antonic, E. S. Sena, J. S. Lees et al., "Stem cell transplantation in traumatic spinal cord injury: a systematic review and meta-analysis of animal studies," PLoS Biology, vol. 11, no. 12, article e1001738, 2013.

[80] K. A. Chang, J. H. Lee, and Y. H. Suh, "Therapeutic potential of human adipose-derived stem cells in neurological disorders," Journal of Pharmacological Sciences, vol. 126, no. 4, pp. 293-301, 2014.

[81] F. H. Gage, "Mammalian neural stem cells," Science, vol. 287, no. 5457, pp. 1433-1438, 2000.

[82] E. Mezey, "The therapeutic potential of bone marrow-derived stromal cells," Journal of Cellular Biochemistry, vol. 112, no. 10, pp. 2683-2687, 2011.

[83] M. Wernig, J. P. Zhao, J. Pruszak et al., "Neurons derived from reprogrammed fibroblasts functionally integrate into the fetal brain and improve symptoms of rats with Parkinson's disease," Proceedings of the National Academy of Sciences of the United States of America, vol. 105, no. 15, pp. 5856-5861, 2008.

[84] Y. Liu, J. P. Weick, H. Liu et al., "Medial ganglionic eminencelike cells derived from human embryonic stem cells correct learning and memory deficits," Nature Biotechnology, vol. 31, no. 5, pp. 440-447, 2013.

[85] A. Arvidsson, T. Collin, D. Kirik, Z. Kokaia, and O. Lindvall, "Neuronal replacement from endogenous precursors in the adult brain after stroke," Nature Medicine, vol. 8, no. 9, pp. 963-970, 2002.

[86] T. Deierborg, K. Staflin, J. Pesic, L. Roybon, P. Brundin, and C. Lundberg, "Absence of striatal newborn neurons with mature phenotype following defined striatal and cortical excitotoxic brain injuries," Experimental Neurology, vol. 219, no. 1, pp. 363-367, 2009.

[87] S. Gilman, "Pharmacologic management of ischemic stroke: relevance to stem cell therapy," Experimental Neurology, vol. 199, no. 1, pp. 28-36, 2006.

[88] J. Nygren, T. Wieloch, J. Pesic, P. Brundin, and T. Deierborg, "Enriched environment attenuates cell genesis in subventricular zone after focal ischemia in mice and decreases 
migration of newborn cells to the striatum," Stroke, vol. 37, no. 11, pp. 2824-2829, 2006.

[89] R. Sullivan, K. Duncan, T. Dailey, Y. Kaneko, N. Tajiri, and C. V. Borlongan, "A possible new focus for stroke treatment - migrating stem cells," Expert Opinion on Biological Therapy, vol. 15, no. 7, pp. 949-958, 2015.

[90] J. Zhang and M. Chopp, "Cell-based therapy for ischemic stroke," Expert Opinion on Biological Therapy, vol. 13, no. 9, pp. 1229-1240, 2013.

[91] O. Lindvall and Z. Kokaia, "Stem cells in human neurodegenerative disorders - time for clinical translation?," The Journal of Clinical Investigation, vol. 120, no. 1, pp. 2940, 2010.

[92] K. Jin, Y. Zhu, Y. Sun, X. O. Mao, L. Xie, and D. A. Greenberg, "Vascular endothelial growth factor (VEGF) stimulates neurogenesis in vitro and in vivo," Proceedings of the National Academy of Sciences of the United States of America, vol. 99, no. 18, pp. 11946-11950, 2002.

[93] M. H. Donovan, U. Yazdani, R. D. Norris, D. Games, D. C. German, and A. J. Eisch, "Decreased adult hippocampal neurogenesis in the PDAPP mouse model of Alzheimer's disease," The Journal of Comparative Neurology, vol. 495, no. 1, pp. 70-83, 2006.

[94] M. A. Lopez-Toledano and M. L. Shelanski, "Increased neurogenesis in young transgenic mice overexpressing human $\mathrm{APP}_{\mathrm{Sw}}$, Ind," Journal of Alzheimer's Disease, vol. 12, no. 3, pp. 229-240, 2007.

[95] J. A. Thomson, J. Itskovitz-Eldor, S. S. Shapiro et al., "Embryonic stem cell lines derived from human blastocysts," Science, vol. 282, no. 5391, pp. 1145-1147, 1998.

[96] S. M. Chambers, C. A. Fasano, E. P. Papapetrou, M. Tomishima, M. Sadelain, and L. Studer, "Highly efficient neural conversion of human ES and iPS cells by dual inhibition of SMAD signaling," Nature Biotechnology, vol. 27, no. 3, pp. 275-280, 2009.

[97] B. Y. Hu and S. C. Zhang, "Differentiation of spinal motor neurons from pluripotent human stem cells," Nature Protocols, vol. 4, no. 9, pp. 1295-1304, 2009.

[98] R. Krencik, J. P. Weick, Y. Liu, Z. J. Zhang, and S. C. Zhang, "Specification of transplantable astroglial subtypes from human pluripotent stem cells," Nature Biotechnology, vol. 29, no. 6, pp. 528-534, 2011.

[99] S. Kriks, J.-W. Shim, J. Piao et al., "Dopamine neurons derived from human ES cells efficiently engraft in animal models of Parkinson's disease," Nature, vol. 480, no. 7378, pp. 547-551, 2011.

[100] H. Lee, G. A. Shamy, Y. Elkabetz et al., "Directed differentiation and transplantation of human embryonic stem cell-derived motoneurons," Stem Cells, vol. 25, no. 8, pp. 1931-1939, 2007.

[101] S. Malmersjo, I. Liste, O. Dyachok, A. Tengholm, E. Arenas, and P. Uhlen, " $\mathrm{Ca}^{2+}$ and cAMP signaling in human embryonic stem cell-derived dopamine neurons," Stem Cells and Development, vol. 19, no. 9, pp. 1355-1364, 2010.

[102] P. Sacchetti, K. M. Sousa, A. C. Hall et al., "Liver X receptors and oxysterols promote ventral midbrain neurogenesis in vivo and in human embryonic stem cells," Cell Stem Cell, vol. 5, no. 4, pp. 409-419, 2009.

[103] C. J. Bissonnette, L. Lyass, B. J. Bhattacharyya, A. Belmadani, R. J. Miller, and J. A. Kessler, "The controlled generation of functional basal forebrain cholinergic neurons from human embryonic stem cells," Stem Cells, vol. 29, no. 5, pp. 802$811,2011$.

[104] M. S. Cho, Y. E. Lee, J. Y. Kim et al., "Highly efficient and large-scale generation of functional dopamine neurons from human embryonic stem cells," Proceedings of the National Academy of Sciences of the United States of America, vol. 105, no. 9, pp. 3392-3397, 2008.

[105] P. Koch, T. Opitz, J. A. Steinbeck, J. Ladewig, and O. Brustle, "A rosette-type, self-renewing human ES cell-derived neural stem cell with potential for in vitro instruction and synaptic integration," Proceedings of the National Academy of Sciences of the United States of America, vol. 106, no. 9, pp. 32253230, 2009.

[106] M. L. Condic and M. Rao, "Alternative sources of pluripotent stem cells: ethical and scientific issues revisited," Stem Cells and Development, vol. 19, no. 8, pp. 1121-1129, 2010.

[107] A. Liras, "Future research and therapeutic applications of human stem cells: general, regulatory, and bioethical aspects," Journal of Translational Medicine, vol. 8, no. 1, p. $131,2010$.

[108] K. Takahashi and S. Yamanaka, "Induction of pluripotent stem cells from mouse embryonic and adult fibroblast cultures by defined factors," Cell, vol. 126, no. 4, pp. 663676, 2006.

[109] O. Cooper, G. Hargus, M. Deleidi et al., "Differentiation of human ES and Parkinson's disease iPS cells into ventral midbrain dopaminergic neurons requires a high activity form of SHH, FGF8a and specific regionalization by retinoic acid," Molecular and Cellular Neuroscience, vol. 45, no. 3, pp. 258266, 2010.

[110] S. Nori, Y. Okada, A. Yasuda et al., "Grafted humaninduced pluripotent stem-cell-derived neurospheres promote motor functional recovery after spinal cord injury in mice," Proceedings of the National Academy of Sciences of the United States of America, vol. 108, no. 40, pp. 1682516830, 2011.

[111] D. Paull, A. Sevilla, H. Zhou et al., "Automated, highthroughput derivation, characterization and differentiation of induced pluripotent stem cells," Nature Methods, vol. 12, no. 9, pp. 885-892, 2015.

[112] T. G. Kim, R. Yao, T. Monnell et al., "Efficient specification of interneurons from human pluripotent stem cells by dorsoventral and rostrocaudal modulation," Stem Cells, vol. 32, no. 7, pp. 1789-1804, 2014.

[113] A. M. Maroof, S. Keros, J. A. Tyson et al., "Directed differentiation and functional maturation of cortical interneurons from human embryonic stem cells," Cell Stem Cell, vol. 12, no. 5, pp. 559-572, 2013.

[114] C. R. Nicholas, J. Chen, Y. Tang et al., "Functional maturation of hPSC-derived forebrain interneurons requires an extended timeline and mimics human neural development," Cell Stem Cell, vol. 12, no. 5, pp. 573-586, 2013.

[115] I. R. Holtman, D. D. Raj, J. A. Miller et al., "Induction of a common microglia gene expression signature by aging and neurodegenerative conditions: a co-expression metaanalysis," Acta Neuropathologica Communications, vol. 3, no. 1, p. 31, 2015.

[116] K. Takamatsu, T. Ikeda, M. Haruta et al., "Degradation of amyloid beta by human induced pluripotent stem cellderived macrophages expressing Neprilysin-2," Stem Cell Research, vol. 13, no. 3, Part A, pp. 442-453, 2014. 
[117] R. Araki, M. Uda, Y. Hoki et al., "Negligible immunogenicity of terminally differentiated cells derived from induced pluripotent or embryonic stem cells," Nature, vol. 494, no. 7435, pp. 100-104, 2013.

[118] Y. Hibaoui and A. Feki, "Human pluripotent stem cells: applications and challenges in neurological diseases," Frontiers in Physiology, vol. 3, p. 267, 2012.

[119] R. Lister, M. Pelizzola, Y. S. Kida et al., "Hotspots of aberrant epigenomic reprogramming in human induced pluripotent stem cells," Nature, vol. 471, no. 7336, pp. 68-73, 2011.

[120] L. Tolosa, E. Pareja, and M. J. Gomez-Lechon, "Clinical application of pluripotent stem cells: an alternative cellbased therapy for treating liver diseases?," Transplantation, vol. 100, no. 12, pp. 2548-2557, 2016.

[121] T. Zhao, Z. N. Zhang, Z. Rong, and Y. Xu, "Immunogenicity of induced pluripotent stem cells," Nature, vol. 474, no. 7350, pp. 212-215, 2011.

[122] G. P. Lomax, S. C. Hull, J. Lowenthal, M. Rao, and R. Isasi, "The DISCUSS project: induced pluripotent stem cell lines from previously collected research biospecimens and informed consent: points to consider," Stem Cells Translational Medicine, vol. 2, no. 10, pp. 727-730, 2013.

[123] J. Lowenthal, S. Lipnick, M. Rao, and S. C. Hull, "Specimen collection for induced pluripotent stem cell research: harmonizing the approach to informed consent," Stem Cells Translational Medicine, vol. 1, no. 5, pp. 409-421, 2012.

[124] S. H. Choi, Y. H. Kim, M. Hebisch et al., "A threedimensional human neural cell culture model of Alzheimer's disease," Nature, vol. 515, no. 7526, pp. 274-278, 2014.

[125] T. Kondo, M. Asai, K. Tsukita et al., "Modeling Alzheimer's disease with iPSCs reveals stress phenotypes associated with intracellular $\mathrm{A} \beta$ and differential drug responsiveness," Cell Stem Cell, vol. 12, no. 4, pp. 487-496, 2013.

[126] Q. Liu, S. Waltz, G. Woodruff et al., "Effect of potent $\gamma$-secretase modulator in human neurons derived from multiple presenilin 1-induced pluripotent stem cell mutant carriers," JAMA Neurology, vol. 71, no. 12, pp. 14811489, 2014.

[127] A. A. Sproul, S. Jacob, D. Pre et al., "Characterization and molecular profiling of PSEN1 familial Alzheimer's disease iPSC-derived neural progenitors," PLoS One, vol. 9, no. 1, article e84547, 2014.

[128] J. Tang, H. Xu, X. Fan et al., "Embryonic stem cell-derived neural precursor cells improve memory dysfunction in A $\beta(1-40)$ injured rats," Neuroscience Research, vol. 62, no. 2, pp. 86-96, 2008.

[129] T. Yagi, A. Kosakai, D. Ito et al., "Establishment of induced pluripotent stem cells from centenarians for neurodegenerative disease research," PLoS One, vol. 7, no. 7, article e41572, 2012.

[130] T. Yagi, D. Ito, Y. Okada et al., "Modeling familial Alzheimer's disease with induced pluripotent stem cells," Human Molecular Genetics, vol. 20, no. 23, pp. 4530-4539, 2011.

[131] M. A. Israel, S. H. Yuan, C. Bardy et al., "Probing sporadic and familial Alzheimer's disease using induced pluripotent stem cells," Nature, vol. 482, no. 7384, pp. 216220, 2012.

[132] A. E. Pen and U. B. Jensen, "Current status of treating neurodegenerative disease with induced pluripotent stem cells," Acta Neurologica Scandinavica, vol. 135, no. 1, pp. 57-72, 2017.
[133] B. Y. Hu, J. P. Weick, J. Yu et al., "Neural differentiation of human induced pluripotent stem cells follows developmental principles but with variable potency," Proceedings of the National Academy of Sciences of the United States of America, vol. 107, no. 9, pp. 4335-4340, 2010.

[134] Z. Wang, W. Peng, C. Zhang et al., "Effects of stem cell transplantation on cognitive decline in animal models of Alzheimer's disease: a systematic review and meta-analysis," Scientific Reports, vol. 5, no. 1, article 12134, 2015.

[135] A. Hermann and A. Storch, "Induced neural stem cells (iNSCs) in neurodegenerative diseases," Journal of Neural Transmission, vol. 120, Supplement 1, pp. S19-S25, 2013.

[136] D. X. Yu, M. C. Marchetto, and F. H. Gage, "Therapeutic translation of iPSCs for treating neurological disease," Cell Stem Cell, vol. 12, no. 6, pp. 678-688, 2013.

[137] S. H. Yuan, J. Martin, J. Elia et al., "Cell-surface marker signatures for the isolation of neural stem cells, glia and neurons derived from human pluripotent stem cells," PLoS One, vol. 6, no. 3, article e17540, 2011.

[138] H. J. Lee, K. S. Kim, E. J. Kim et al., "Brain transplantation of immortalized human neural stem cells promotes functional recovery in mouse intracerebral hemorrhage stroke model," Stem Cells, vol. 25, no. 5, pp. 1204-1212, 2007.

[139] A. G. Xuan, D. H. Long, H. G. Gu, D. D. Yang, L. P. Hong, and S. L. Leng, "BDNF improves the effects of neural stem cells on the rat model of Alzheimer's disease with unilateral lesion of fimbria-fornix," Neuroscience Letters, vol. 440, no. 3, pp. 331-335, 2008.

[140] A. G. Xuan, M. Luo, W. D. Ji, and D. H. Long, "Effects of engrafted neural stem cells in Alzheimer's disease rats," Neuroscience Letters, vol. 450, no. 2, pp. 167-171, 2009.

[141] T. R. Yamasaki, M. Blurton-Jones, D. A. Morrissette, M. Kitazawa, S. Oddo, and F. M. LaFerla, "Neural stem cells improve memory in an inducible mouse model of neuronal loss," The Journal of Neuroscience, vol. 27, no. 44, pp. 11925-11933, 2007.

[142] L. M. Tong, H. Fong, and Y. Huang, "Stem cell therapy for Alzheimer's disease and related disorders: current status and future perspectives," Experimental \& Molecular Medicine, vol. 47, no. 3, article e151, 2015.

[143] C. Chen and S. F. Xiao, "Induced pluripotent stem cells and neurodegenerative diseases," Neuroscience Bulletin, vol. 27, no. 2, pp. 107-114, 2011.

[144] S. Wu, A. Sasaki, R. Yoshimoto et al., "Neural stem cells improve learning and memory in rats with Alzheimer's disease," Pathobiology, vol. 75, no. 3, pp. 186-194, 2008.

[145] S. U. Kim, H. J. Lee, and Y. B. Kim, "Neural stem cell-based treatment for neurodegenerative diseases," Neuropathology, vol. 33, no. 5, pp. 491-504, 2013.

[146] F. H. Moghadam, H. Alaie, K. Karbalaie, S. Tanhaei, M. H. Nasr Esfahani, and H. Baharvand, "Transplantation of primed or unprimed mouse embryonic stem cellderived neural precursor cells improves cognitive function in Alzheimerian rats," Differentiation, vol. 78, no. 2-3, pp. 59-68, 2009.

[147] J. H. Kordower, S. R. Winn, Y. T. Liu et al., “The aged monkey basal forebrain: rescue and sprouting of axotomized basal forebrain neurons after grafts of encapsulated cells secreting human nerve growth factor," Proceedings of the National Academy of Sciences of the United States of America, vol. 91, no. 23, pp. 10898-10902, 1994. 
[148] M. Blurton-Jones, M. Kitazawa, H. Martinez-Coria et al., "Neural stem cells improve cognition via BDNF in a transgenic model of Alzheimer disease," Proceedings of the National Academy of Sciences of the United States of America, vol. 106, no. 32, pp. 13594-13599, 2009.

[149] W. W. Chen and M. Blurton-Jones, "Concise review: can stem cells be used to treat or model Alzheimer's disease?," Stem Cells, vol. 30, no. 12, pp. 2612-2618, 2012.

[150] R. R. Ager, J. L. Davis, A. Agazaryan et al., "Human neural stem cells improve cognition and promote synaptic growth in two complementary transgenic models of Alzheimer's disease and neuronal loss," Hippocampus, vol. 25, no. 7, pp. 813-826, 2015.

[151] I. S. Lee, K. Jung, I. S. Kim et al., "Human neural stem cells alleviate Alzheimer-like pathology in a mouse model," Molecular Neurodegeneration, vol. 10, no. 1, p. 38, 2015.

[152] A. M. Lilja, L. Malmsten, J. Röjdner et al., "Neural stem cell transplant-induced effect on neurogenesis and cognition in Alzheimer Tg2576 mice is inhibited by concomitant treatment with amyloid-lowering or cholinergic $\alpha 7$ nicotinic receptor drugs," Neural Plasticity, vol. 2015, Article ID 370432, 13 pages, 2015.

[153] Q. Zhang, H. Wu, Y. Wang, G. Gu, W. Zhang, and R. Xia, "Neural stem cell transplantation decreases neuroinflammation in a transgenic mouse model of Alzheimer's disease," Journal of Neurochemistry, vol. 136, no. 4, pp. 815-825, 2015.

[154] D. W. Han, N. Tapia, A. Hermann et al., "Direct reprogramming of fibroblasts into neural stem cells by defined factors," Cell Stem Cell, vol. 10, no. 4, pp. 465-472, 2012.

[155] S. M. Kim, H. Flaßkamp, A. Hermann et al., "Direct conversion of mouse fibroblasts into induced neural stem cells," Nature Protocols, vol. 9, no. 4, pp. 871-881, 2014.

[156] E. Lujan, S. Chanda, H. Ahlenius, T. C. Sudhof, and M. Wernig, "Direct conversion of mouse fibroblasts to self-renewing, tripotent neural precursor cells," Proceedings of the National Academy of Sciences of the United States of America, vol. 109, no. 7, pp. 2527-2532, 2012.

[157] K. L. Ring, L. M. Tong, M. E. Balestra et al., "Direct reprogramming of mouse and human fibroblasts into multipotent neural stem cells with a single factor," Cell Stem Cell, vol. 11, no. 1, pp. 100-109, 2012.

[158] M. Thier, P. Wörsdörfer, Y. B. Lakes et al., "Direct conversion of fibroblasts into stably expandable neural stem cells," Cell Stem Cell, vol. 10, no. 4, pp. 473-479, 2012.

[159] Q. Zhou and P. Tripathi, "How to remake a fibroblast into a neural stem cell," Cell Stem Cell, vol. 10, no. 4, pp. 347348, 2012.

[160] S. Corti, M. Nizzardo, C. Simone et al., "Direct reprogramming of human astrocytes into neural stem cells and neurons," Experimental Cell Research, vol. 318, no. 13, pp. 1528-1541, 2012.

[161] C. Sheng, Q. Zheng, J. Wu et al., "Direct reprogramming of Sertoli cells into multipotent neural stem cells by defined factors," Cell Research, vol. 22, no. 1, pp. 208-218, 2012.

[162] M. Li, K. Guo, and S. Ikehara, "Stem cell treatment for Alzheimer's disease," International Journal of Molecular Sciences, vol. 15, no. 10, pp. 19226-19238, 2014.

[163] K. Hemmer, M. Zhang, T. van Wüllen et al., "Induced neural stem cells achieve long-term survival and functional integration in the adult mouse brain," Stem Cell Reports, vol. 3, no. 3, pp. 423-431, 2014.
[164] S. Q. Chen, Q. Cai, Y. Y. Shen et al., " ${ }^{1} H-M R S$ evaluation of therapeutic effect of neural stem cell transplantation on Alzheimer's disease in A $\beta P P / P S 1$ double transgenic mice," Journal of Alzheimer's Disease, vol. 28, no. 1, pp. 7180, 2012.

[165] S. S. Choi, S. R. Lee, S. U. Kim, and H. J. Lee, “Alzheimer's disease and stem cell therapy," Experimental Neurobiology, vol. 23, no. 1, pp. 45-52, 2014.

[166] S. B. Dunnett and A. E. Rosser, "Challenges for taking primary and stem cells into clinical neurotransplantation trials for neurodegenerative disease," Neurobiology of Disease, vol. 61, pp. 79-89, 2014

[167] M. S. Divya, G. E. Roshin, T. S. Divya et al., "Umbilical cord blood-derived mesenchymal stem cells consist of a unique population of progenitors co-expressing mesenchymal stem cell and neuronal markers capable of instantaneous neuronal differentiation," Stem Cell Research \& Therapy, vol. 3, no. 6, p. $57,2012$.

[168] S. H. Oh, H. N. Kim, H. J. Park, J. Y. Shin, and P. H. Lee, "Mesenchymal stem cells increase hippocampal neurogenesis and neuronal differentiation by enhancing the Wnt signaling pathway in an Alzheimer's disease model," Cell Transplantation, vol. 24, no. 6, pp. 1097-1109, 2015.

[169] J. C. Ra, I. S. Shin, S. H. Kim et al., "Safety of intravenous infusion of human adipose tissue-derived mesenchymal stem cells in animals and humans," Stem Cells and Development, vol. 20, no. 8, pp. 1297-1308, 2011.

[170] J. Lee, S. Kuroda, H. Shichinohe et al., "Migration and differentiation of nuclear fluorescence-labeled bone marrow stromal cells after transplantation into cerebral infarct and spinal cord injury in mice," Neuropathology, vol. 23, no. 3, pp. 169-180, 2003.

[171] S. U. Kim, H. J. Oh, I. R. Wanless, S. Lee, K. H. Han, and Y. N. Park, "The Laennec staging system for histological sub-classification of cirrhosis is useful for stratification of prognosis in patients with liver cirrhosis," Journal of Hepatology, vol. 57, no. 3, pp. 556-563, 2012.

[172] J. R. Munoz, B. R. Stoutenger, A. P. Robinson, J. L. Spees, and D. J. Prockop, "Human stem/progenitor cells from bone marrow promote neurogenesis of endogenous neural stem cells in the hippocampus of mice," Proceedings of the National Academy of Sciences of the United States of America, vol. 102, no. 50, pp. 18171-18176, 2005.

[173] F. G. Teixeira, M. M. Carvalho, A. Neves-Carvalho et al., "Secretome of mesenchymal progenitors from the umbilical cord acts as modulator of neural/glial proliferation and differentiation," Stem Cell Reviews and Reports, vol. 11, no. 2, pp. 288-297, 2015.

[174] N. Zilka, M. Zilkova, Z. Kazmerova, M. Sarissky, V. Cigankova, and M. Novak, "Mesenchymal stem cells rescue the Alzheimer's disease cell model from cell death induced by misfolded truncated tau," Neuroscience, vol. 193, pp. 330-337, 2011.

[175] K. S. Kim, H. S. Kim, J. M. Park et al., "Long-term immunomodulatory effect of amniotic stem cells in an Alzheimer's disease model," Neurobiology of Aging, vol. 34, no. 10, pp. 2408-2420, 2013.

[176] Y. Naaldijk, C. Jäger, C. Fabian et al., "Effect of systemic transplantation of bone marrow-derived mesenchymal stem cells on neuropathology markers in APP/PS1 Alzheimer mice," Neuropathology and Applied Neurobiology, vol. 43, no. 4, pp. 299-314, 2017. 
[177] H. Yang, Z. Xie, L. Wei et al., "Human umbilical cord mesenchymal stem cell-derived neuron-like cells rescue memory deficits and reduce amyloid-beta deposition in an AbetaPP/ PS1 transgenic mouse model," Stem Cell Research \& Therapy, vol. 4, no. 4, p. 76, 2013.

[178] H. M. Yun, H. S. Kim, K. R. Park et al., "Placenta-derived mesenchymal stem cells improve memory dysfunction in an $\mathrm{A} \beta_{1-42}$-infused mouse model of Alzheimer's disease," Cell Death \& Disease, vol. 4, no. 12, article e958, 2013.

[179] W. Zaher, L. Harkness, A. Jafari, and M. Kassem, “An update of human mesenchymal stem cell biology and their clinical uses," Archives of Toxicology, vol. 88, no. 5, pp. 1069-1082, 2014.

[180] S. Aggarwal and M. F. Pittenger, "Human mesenchymal stem cells modulate allogeneic immune cell responses," Blood, vol. 105, no. 4, pp. 1815-1822, 2005.

[181] S. Beyth, Z. Borovsky, D. Mevorach et al., "Human mesenchymal stem cells alter antigen-presenting cell maturation and induce T-cell unresponsiveness," Blood, vol. 105, no. 5, pp. 2214-2219, 2005.

[182] R. Ramasamy, H. Fazekasova, E. W.-F. Lam, I. Soeiro, G. Lombardi, and F. Dazzi, "Mesenchymal stem cells inhibit dendritic cell differentiation and function by preventing entry into the cell cycle," Transplantation, vol. 83, no. 1, pp. 71-76, 2007.

[183] J. M. Ryan, F. Barry, J. M. Murphy, and B. P. Mahon, "Interferon- $\gamma$ does not break, but promotes the immunosuppressive capacity of adult human mesenchymal stem cells," Clinical \& Experimental Immunology, vol. 149, no. 2, pp. 353-363, 2007.

[184] P. A. Sotiropoulou, S. A. Perez, A. D. Gritzapis, C. N. Baxevanis, and M. Papamichail, "Interactions between human mesenchymal stem cells and natural killer cells," Stem Cells, vol. 24, no. 1, pp. 74-85, 2006.

[185] J. Chen, Y. X. Tang, Y. M. Liu et al., "Transplantation of adipose-derived stem cells is associated with neural differentiation and functional improvement in a rat model of intracerebral hemorrhage," CNS Neuroscience \& Therapeutics, vol. 18, no. 10, pp. 847-854, 2012.

[186] J. Case, T. L. Horvath, C. B. Ballas, K. L. March, and E. F. Srour, "In vitro clonal analysis of murine pluripotent stem cells isolated from skeletal muscle and adipose stromal cells," Experimental Hematology, vol. 36, no. 2, pp. 224234, 2008.

[187] D. Peroni, I. Scambi, A. Pasini et al., "Stem molecular signature of adipose-derived stromal cells," Experimental Cell Research, vol. 314, no. 3, pp. 603-615, 2008.

[188] M. Gutiérrez-Fernández, B. Rodríguez-Frutos, J. RamosCejudo et al., "Effects of intravenous administration of allogenic bone marrow- and adipose tissue-derived mesenchymal stem cells on functional recovery and brain repair markers in experimental ischemic stroke," Stem Cell Research \& Therapy, vol. 4, no. 1, p. 11, 2013.

[189] Y. Ikegame, K. Yamashita, S. Hayashi et al., "Comparison of mesenchymal stem cells from adipose tissue and bone marrow for ischemic stroke therapy," Cytotherapy, vol. 13, no. 6, pp. 675-685, 2011.

[190] S. Leu, Y. C. Lin, C. M. Yuen et al., "Adipose-derived mesenchymal stem cells markedly attenuate brain infarct size and improve neurological function in rats," Journal of Translational Medicine, vol. 8, no. 1, p. 63, 2010.
[191] S. Lu, C. Lu, Q. Han et al., "Adipose-derived mesenchymal stem cells protect PC12 cells from glutamate excitotoxicityinduced apoptosis by upregulation of XIAP through PI3-K/ Akt activation," Toxicology, vol. 279, no. 1-3, pp. 189195, 2011.

[192] X. Wei, L. Zhao, J. Zhong et al., "Adipose stromal cellssecreted neuroprotective media against neuronal apoptosis," Neuroscience Letters, vol. 462, no. 1, pp. 76-79, 2009.

[193] K. L. Yang, J. T. Lee, C. Y. Pang et al., "Human adiposederived stem cells for the treatment of intracerebral hemorrhage in rats via femoral intravenous injection," Cellular and Molecular Biology Letters, vol. 17, no. 3, pp. 376392, 2012.

[194] J. M. Kang, B. K. Yeon, S. J. Cho, and Y. H. Suh, "Stem cell therapy for Alzheimer's disease: a review of recent clinical trials," Journal of Alzheimer's Disease, vol. 54, no. 3, pp. 879-889, 2016.

[195] D. Darlington, J. Deng, B. Giunta et al., "Multiple low-dose infusions of human umbilical cord blood cells improve cognitive impairments and reduce amyloid-beta-associated neuropathology in Alzheimer mice," Stem Cells and Development, vol. 22, no. 3, pp. 412-421, 2013.

[196] K. J. L. Fernandes, N. R. Kobayashi, C. J. Gallagher et al., "Analysis of the neurogenic potential of multipotent skin-derived precursors," Experimental Neurology, vol. 201, no. 1, pp. 32-48, 2006.

[197] K. J. L. Fernandes, I. A. McKenzie, P. Mill et al., "A dermal niche for multipotent adult skin-derived precursor cells," Nature Cell Biology, vol. 6, no. 11, pp. 1082-1093, 2004.

[198] Y. F. Hu, K. Gourab, C. Wells, O. Clewes, B. D. Schmit, and M. Sieber-Blum, "Epidermal neural crest stem cell (EPI-NCSC)-mediated recovery of sensory function in a mouse model of spinal cord injury," Stem Cell Reviews and Reports, vol. 6, no. 2, pp. 186-198, 2010.

[199] E. Krejci and M. Grim, "Isolation and characterization of neural crest stem cells from adult human hair follicles," Folia Biologica, vol. 56, no. 4, pp. 149-157, 2010.

[200] M. Sieber-Blum, M. Grim, Y. F. Hu, and V. Szeder, "Pluripotent neural crest stem cells in the adult hair follicle," Developmental Dynamics, vol. 231, no. 2, pp. 258-269, 2004.

[201] W. V. Nikolic, H. Hou, T. Town et al., "Peripherally administered human umbilical cord blood cells reduce parenchymal and vascular $\beta$-amyloid deposits in Alzheimer mice," Stem Cells and Development, vol. 17, no. 3, pp. 423440, 2008.

[202] A. Arthur, G. Rychkov, S. Shi, S. A. Koblar, and S. Gronthos, "Adult human dental pulp stem cells differentiate toward functionally active neurons under appropriate environmental cues," Stem Cells, vol. 26, no. 7, pp. 17871795, 2008.

[203] A. Arthur, S. Shi, A. C. W. Zannettino, N. Fujii, S. Gronthos, and S. A. Koblar, "Implanted adult human dental pulp stem cells induce endogenous axon guidance," Stem Cells, vol. 27, no. 9, pp. 2229-2237, 2009.

[204] W. K. Leong, T. L. Henshall, A. Arthur et al., "Human adult dental pulp stem cells enhance poststroke functional recovery through non-neural replacement mechanisms," Stem Cells Translational Medicine, vol. 1, no. 3, pp. 177-187, 2012.

[205] R. Deumens, G. C. Koopmans, W. M. M. Honig et al., "Chronically injured corticospinal axons do not cross large spinal lesion gaps after a multifactorial transplantation strategy 
using olfactory ensheathing cell/olfactory nerve fibroblastbiomatrix bridges," Journal of Neuroscience Research, vol. 83, no. 5, pp. 811-820, 2006.

[206] T. Imaizumi, K. L. Lankford, S. G. Waxman, C. A. Greer, and J. D. Kocsis, "Transplanted olfactory ensheathing cells remyelinate and enhance axonal conduction in the demyelinated dorsal columns of the rat spinal cord," The Journal of Neuroscience, vol. 18, no. 16, pp. 6176-6185, 1998.

[207] Y. Li, P. M. Field, and G. Raisman, "Regeneration of adult rat corticospinal axons induced by transplanted olfactory ensheathing cells," The Journal of Neuroscience, vol. 18, no. 24, pp. 10514-10524, 1998.

[208] C. Munoz-Quiles, F. F. Santos-Benito, M. B. Llamusi, and A. Ramon-Cueto, "Chronic spinal injury repair by olfactory bulb ensheathing glia and feasibility for autologous therapy," Journal of Neuropathology \& Experimental Neurology, vol. 68, no. 12, pp. 1294-1308, 2009.

[209] A. Ramon-Cueto and J. Avila, "Olfactory ensheathing glia: properties and function," Brain Research Bulletin, vol. 46, no. 3, pp. 175-187, 1998.

[210] A. Ramon-Cueto, M. I. Cordero, F. F. Santos-Benito, and J. Avila, "Functional recovery of paraplegic rats and motor axon regeneration in their spinal cords by olfactory ensheathing glia," Neuron, vol. 25, no. 2, pp. 425-435, 2000.

[211] A. M. Baig, "Designer's microglia with novel delivery system in neurodegenerative diseases," Medical Hypotheses, vol. 83, no. 4, pp. 510-512, 2014.

[212] A. M. Baig and N. A. Khan, "Novel chemotherapeutic strategies in the management of primary amoebic meningoencephalitis due to Naegleria fowleri," CNS Neuroscience \& Therapeutics, vol. 20, no. 3, pp. 289-290, 2014.

[213] L. Danielyan, S. Beer-Hammer, A. Stolzing et al., "Intranasal delivery of bone marrow-derived mesenchymal stem cells, macrophages, and microglia to the brain in mouse models of Alzheimer's and Parkinson's disease," Cell Transplantation, vol. 23, Supplement 1, pp. S123-S139, 2014.

[214] M. Tachibana, P. Amato, M. Sparman et al., "Human embryonic stem cells derived by somatic cell nuclear transfer," Cell, vol. 153, no. 6, pp. 1228-1238, 2013.

[215] G. Vertelov, L. Kharazi, M. G. Muralidhar, G. Sanati, T. Tankovich, and A. Kharazi, "High targeted migration of human mesenchymal stem cells grown in hypoxia is associated with enhanced activation of RhoA," Stem Cell Research \& Therapy, vol. 4, no. 1, p. 5, 2013.

[216] C. Andressen, "Neural stem cells: from neurobiology to clinical applications," Current Pharmaceutical Biotechnology, vol. 14, no. 1, pp. 20-28, 2013.

[217] C. V. Borlongan, "Recent preclinical evidence advancing cell therapy for Alzheimer's disease," Experimental Neurology, vol. 237, no. 1, pp. 142-146, 2012.

[218] X. Fan, D. Sun, X. Tang, Y. Cai, Z. Q. Yin, and H. Xu, “Stemcell challenges in the treatment of Alzheimer's disease: a long way from bench to bedside," Medicinal Research Reviews, vol. 34, no. 5, pp. 957-978, 2014.

[219] M. J. Glat and D. Offen, "Cell and gene therapy in Alzheimer's disease," Stem Cells and Development, vol. 22, no. 10, pp. 1490-1496, 2013.

[220] S. Hitoshi, V. Tropepe, M. Ekker, and D. van der Kooy, "Neural stem cell lineages are regionally specified, but not committed, within distinct compartments of the developing brain," Development, vol. 129, no. 1, pp. 233-244, 2002.
[221] H. Okano and S. Temple, "Cell types to order: temporal specification of CNS stem cells," Current Opinion in Neurobiology, vol. 19, no. 2, pp. 112-119, 2009.

[222] C. Bock, E. Kiskinis, G. Verstappen et al., "Reference maps of human ES and iPS cell variation enable high-throughput characterization of pluripotent cell lines," Cell, vol. 144, no. 3, pp. 439-452, 2011.

[223] G. L. Boulting, E. Kiskinis, G. F. Croft et al., “A functionally characterized test set of human induced pluripotent stem cells," Nature Biotechnology, vol. 29, no. 3, pp. 279-286, 2011.

[224] N. Amariglio, A. Hirshberg, B. W. Scheithauer et al., "Donor-derived brain tumor following neural stem cell transplantation in an ataxia telangiectasia patient," PLoS Medicine, vol. 6, no. 2, article e1000029, 2009.

[225] S. S. Fazel, D. Angoulvant, J. Butany, R. D. Weisel, and R. K. $\mathrm{Li}$, "Mesenchymal stem cells engineered to overexpress stem cell factor improve cardiac function but have malignant potential," The Journal of Thoracic and Cardiovascular Surgery, vol. 136, no. 5, pp. 1388-1389, 2008.

[226] J. G. Hunsberger, M. Rao, J. Kurtzberg et al., "Accelerating stem cell trials for Alzheimer's disease," The Lancet Neurology, vol. 15, no. 2, pp. 219-230, 2016.

[227] D. Thirabanjasak, K. Tantiwongse, and P. S. Thorner, "Angiomyeloproliferative lesions following autologous stem cell therapy," Journal of the American Society of Nephrology, vol. 21, no. 7, pp. 1218-1222, 2010.

[228] D. J. Pappas, P. A. Gourraud, C. Le Gall et al., "Proceedings: human leukocyte antigen haplo-homozygous induced pluripotent stem cell haplobank modeled after the California population: evaluating matching in a multiethnic and admixed population," Stem Cells Translational Medicine, vol. 4, no. 5, pp. 413-418, 2015.

[229] S. M. Cromer Berman, P. Walczak, and J. W. M. Bulte, "Tracking stem cells using magnetic nanoparticles," Wiley Interdisciplinary Reviews: Nanomedicine and Nanobiotechnology, vol. 3, no. 4, pp. 343-355, 2011.

[230] D. Karussis, C. Karageorgiou, A. Vaknin-Dembinsky et al., "Safety and immunological effects of mesenchymal stem cell transplantation in patients with multiple sclerosis and amyotrophic lateral sclerosis," Archives of Neurology, vol. 67, no. 10, pp. 1187-1194, 2010.

[231] A. K. Srivastava, D. K. Kadayakkara, A. Bar-Shir, A. A. Gilad, M. T. McMahon, and J. W. M. Bulte, "Advances in using MRI probes and sensors for in vivo cell tracking as applied to regenerative medicine," Disease Models \& Mechanisms, vol. 8, no. 4, pp. 323-336, 2015.

[232] M. Gorelik, I. Orukari, J. Wang et al., "Use of MR cell tracking to evaluate targeting of glial precursor cells to inflammatory tissue by exploiting the very late antigen-4 docking receptor," Radiology, vol. 265, no. 1, pp. 175-185, 2012.

[233] M. Janowski, A. Lyczek, C. Engels et al., "Cell size and velocity of injection are major determinants of the safety of intracarotid stem cell transplantation," Journal of Cerebral Blood Flow \& Metabolism, vol. 33, no. 6, pp. 921-927, 2013. 


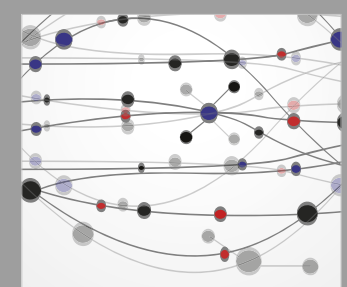

The Scientific World Journal
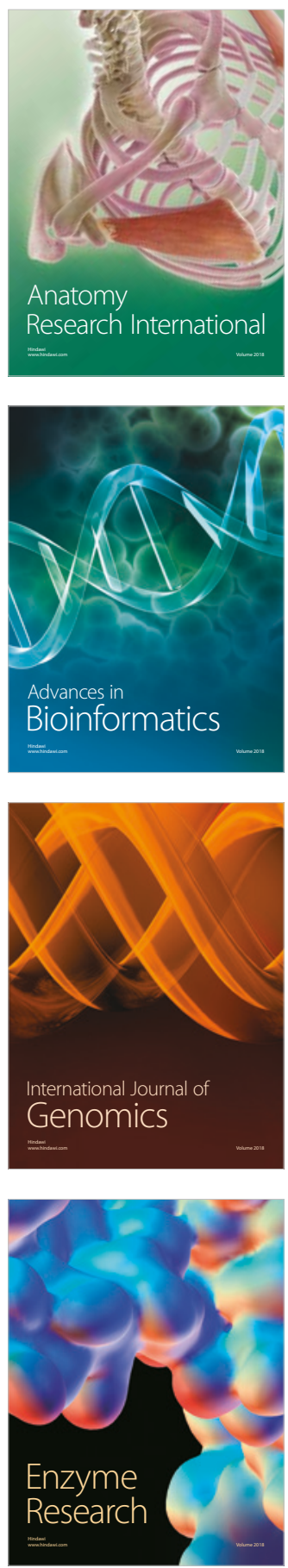
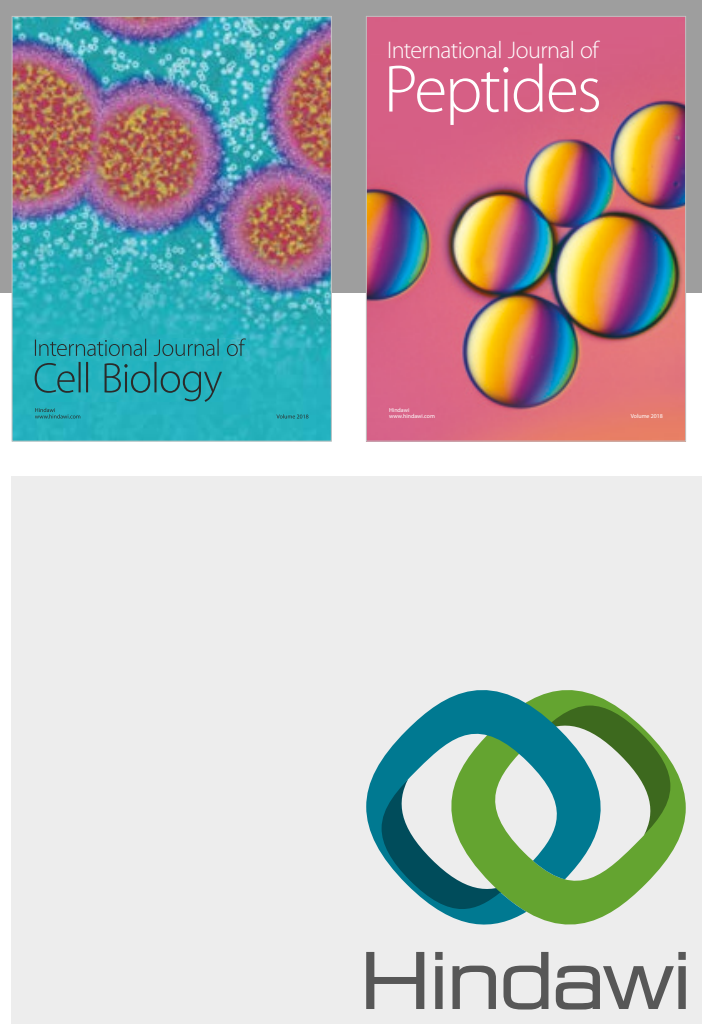

Submit your manuscripts at

www.hindawi.com
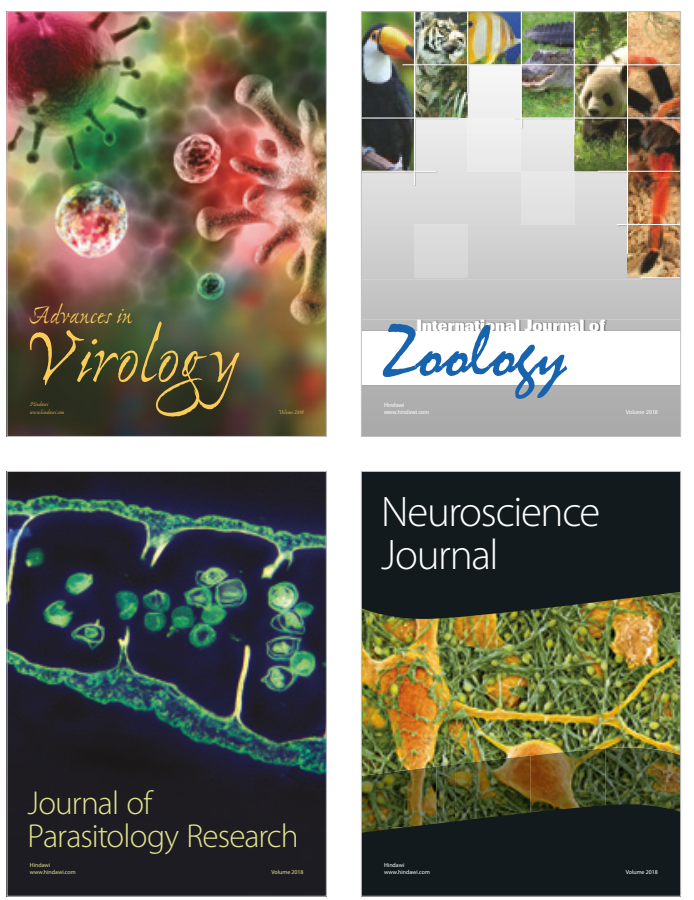
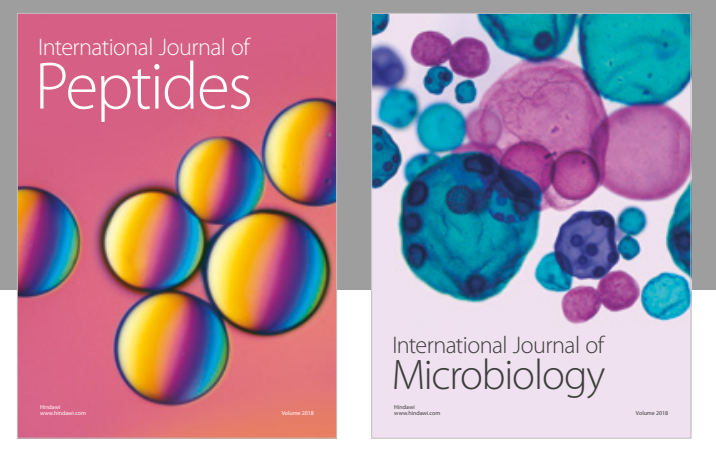

nternational Journal of Microbiology
Journal of
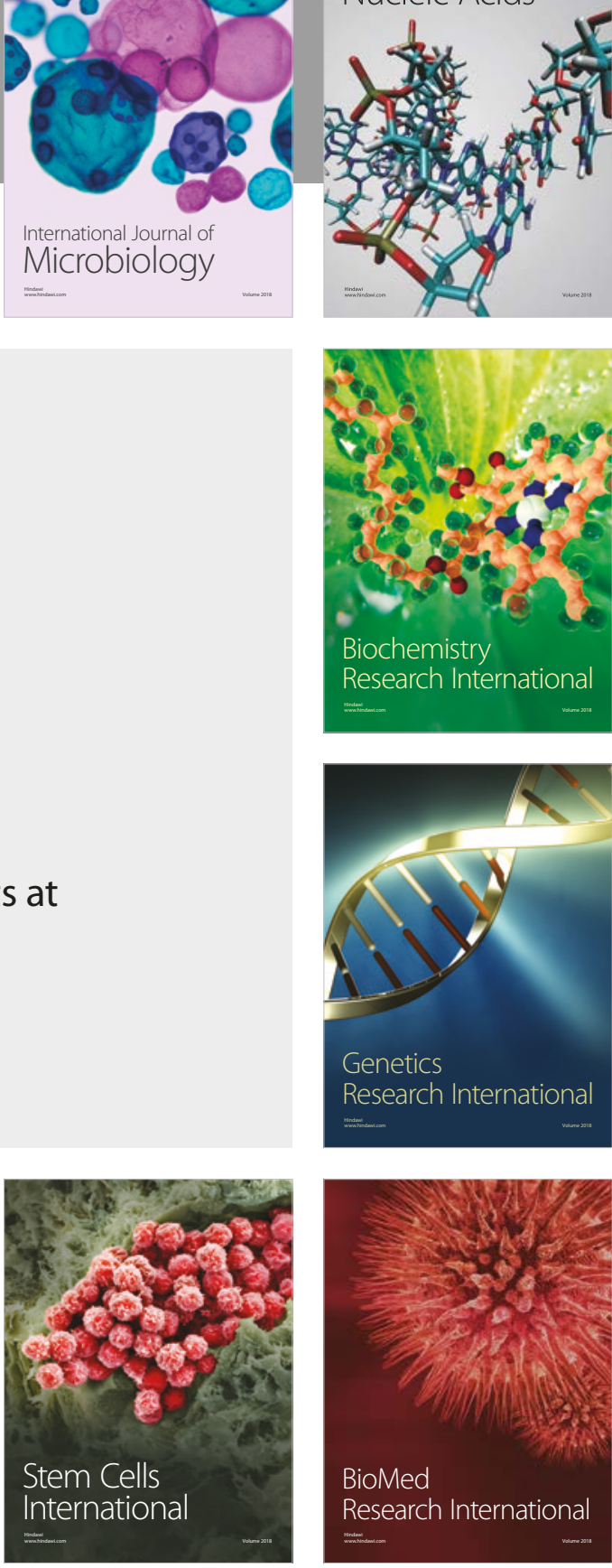
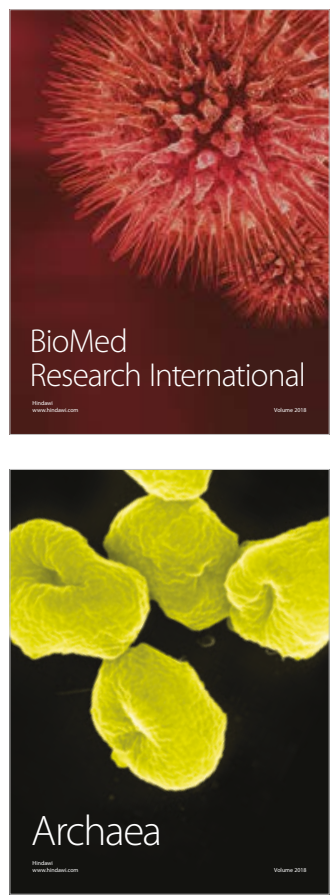